\title{
THE INFLUENCE OF AMMONIUM ION ON THE PLASMA ATA- BRINE LEVEL AND ON THE URINARY EXCRETION OF ATABRINE
}

\author{
BY WILLIAM TRAGER ${ }^{1}$ AND MELVILLE C. HUTCHINSON 2 \\ (From the 19th General Laboratory)
}

(Received for publication March 8, 1946)

In men taking atabrine, the concentration of the drug in the leukocytes is about 400 times that in the plasma, and 100 to 200 times that in the red blood cells (1). Consequently, any appreciable change in the leukocyte count would be reflected by a change in the atabrine level of the whole blood, even though the level in the plasma and erythrocytes remained the same. For this reason, it has been considered essential to "relate the chemotherapeutic activity of atabrine to its concentration in the plasma, rather than its concentration in the whole blood" (1).

In order to avoid measuring any of the atabrine present in the leukocytes, it has been customary to draw blood into an anticoagulant, centrifuge it as soon as possible (preferably within $10 \mathrm{~min}$ utes) for 15 to 20 minutes, and recentrifuge the supernatant plasma for 40 to 60 minutes to remove all white cell fragments. No specifications appear to have been made concerning the anticoagulant used. Brodie and Udenfriend (1) merely state that the blood is drawn into an adequate amount of oxalate. In studies conducted at Fort Knox by the U. S. Army, potassium oxalate was used as the anticoagulant. In the work of a U. S. Army research unit in the Southwest Pacific, sodium oxalate was routinely used.

When an attempt was made to use the Heller and Paul mixture of potassium and ammonium oxalates, which is supposed to have less effect on the properties of the cellular constituents of blood than other oxalate solutions $(2,3)$, it was found that extremely high plasma atabrine levels were obtained.

This observation led to the experiments here reported, which have shown that the ammonium ion has a specific effect in rapidly extracting much of the atabrine from the cellular elements of the blood, and from tissues. Such an effect occurs

1 Capt. Sn.C.

2 Ist Lt. Sn.C. in vivo as well as in vitro. It should be mentioned that, after the completion of the present work, the authors learned through personal communication that the preliminary observations concerning the effect of ammonium ion on plasma levels in vitro had been independently made by a group of British investigators.

\section{EXPERIMENTAL RESULTS}

(1) Atabrine was determined by the single extraction method of Brodie and Udenfriend (1). Urinary ammonia was measured by Folin's aeration method (2).

(2) The preliminary observations need not be given in detail. When blood was prevented from clotting, in exactly the manner recommended for the Phillips-Van Slyke specific gravity determination (3), and the plasma was prepared in the usual way for atabrine assay, plasma atabrine levels of $100 \mu \mathrm{g}$. or more per liter, instead of the expected 20 to $30 \mu$ g., were repeatedly obtained with plasma from individuals taking the suppressive dose of $0.1 \mathrm{gram}$ atabrine daily.

The potassium-ammonium oxalate solution did not yield fluorescent materials when extracted by the same procedures used for blood and plasma. The effect on plasma level was produced mainly by the ammonium oxalate (Table I). This salt, at a concentration of $0.15 \mathrm{M}$, rapidly extracted much of the atabrine from the blood cells, so that the plasma level approached that of the whole

TABLE I

The plasma atabrine levels obtained with 3 different oxalate solutions as anticoagulants Anticoagulant

Sodium oxalate

Potassium oxalate

Ammonium oxalate

Thirty ml. blood were drawn from person taking 0.1 gram atabrine daily. Ten $\mathrm{ml}$. were run into each of 3 tubes containing $1 \mathrm{ml}$. of a 2 per cent solution of the indicated oxalate. The plasmas were prepared in the usual manner. 
blood (Table II). It is evident from Table III that the ammonium ion itself is responsible for the extraction of the atabrine from the cells, and that a concentration of 2 millimolar of ammonium oxalate (4 millimolar ammonium ion concentration) gave almost the maximal effect. That the ammonium ion did not cause some naturally occurring fluorescent constituent of the blood to be extracted into the ethylene dichloride, was shown by the low value of $9 \mu \mathrm{g}$. per liter obtained for the whole blood, collected in ammonium oxalate, of a person who had stopped taking atabrine 8 weeks previously.

(3) Figure 1 shows the relationship which obtains between the concentration of added ammonium ion and the resulting concentration of atabrine in the plasma. For this experiment blood was drawn, from a person taking 0.1 gram atabrine daily, into a suitable quantity of $0.15 \mathrm{M}$ lithium oxalate solution. A small portion was kept for determination of the whole blood level. The rest was divided into 6 portions of $10 \mathrm{ml}$. each, to 5 of which were added very small volumes of ammonium oxalate solution to give the final ammonium ion concentrations of 0.3 to 6.0 millimolar. The tubes were all set centrifuging within $7 \mathrm{~min}$ utes after the blood was drawn, and the plasmas were prepared in the usual manner. All had the same $\mathrm{pH}$. It is interesting to note that if this curve is extrapolated to a plasma atabrine level of

TABLE II

The extraction of atabrine by ammonium ion from the blood cells into the plasma

\begin{tabular}{|c|c|c|c|}
\hline \multirow{3}{*}{$\begin{array}{c}\text { Blood } \\
\text { number }\end{array}$} & \multicolumn{3}{|c|}{ 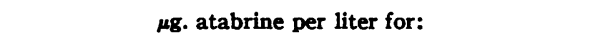 } \\
\hline & \multirow{2}{*}{ Whole blood } & \multicolumn{2}{|c|}{ Plasma } \\
\hline & & Sodium oxalate & Ammonium oxalate \\
\hline 1 & 285 & 26 & 151 \\
\hline 2 & 308 & 33 & 168 \\
\hline 3 & 151 & (lost) & 105 \\
\hline 4 & 280 & 26 & 238 \\
\hline
\end{tabular}

Twenty-five ml. blood were drawn from each of 4 individuals taking 0.1 gram atabrine daily. Fifteen $\mathrm{ml}$. of each blood was added to a tube containing $1.5 \mathrm{ml}$. of 2 per cent sodium oxalate, the remaining $10 \mathrm{ml}$. to a tube with $1 \mathrm{ml}$. of 2 per cent ammonium oxalate. A portion of whole blood was withdrawn from each of the sodium oxalate tubes. The remainder, and the material in the ammonium oxalate tubes, was then used for the preparation of plasma in the usual way.
TABLE III

The specificity of the ammonium ion in rapidly extracting much of the atabrine from the blood cells into the plasma

\begin{tabular}{|c|c|c|c|}
\hline Subject & $\begin{array}{l}\text { Composition of } \\
\text { anticoagulant }\end{array}$ & $\begin{array}{l}\text { Millimolar } \\
\text { concentra- } \\
\text { tion of } \\
\text { added am- } \\
\text { monium } \\
\text { ion in final } \\
\text { mixture }\end{array}$ & Atabrine \\
\hline $\operatorname{Re}$ & $\begin{array}{l}\text { a) } 0.15 \mathrm{M} \text { lithium oxalate } \\
\text { b) } 0.15 \mathrm{M} \text { sodium oxalate } \\
\text { c) } 0.15 \mathrm{M} \text { potassium oxalate }\end{array}$ & $\begin{array}{l}\mathbf{0} \\
\mathbf{0} \\
\mathbf{0}\end{array}$ & \begin{tabular}{|c} 
Mg. per liter \\
of plasme \\
25 \\
25 \\
36
\end{tabular} \\
\hline $\mathbf{B a}$ & $\begin{array}{l}\text { a) } 0.15 \mathrm{M} \text { sodium oxalate } \\
\text { b) } 0.14 \mathrm{M} \text { sodium oxalate } \\
0.01 \mathrm{M} \text { ammonium oxalate } \\
\text { c) } 0.13 \mathrm{M} \text { sodium oxalate } \\
0.02 \mathrm{M} \text { ammonium oxalate }\end{array}$ & $\begin{array}{l}0 \\
1.8 \\
3.6\end{array}$ & $\begin{array}{r}33 \\
127 \\
155\end{array}$ \\
\hline $\mathrm{Bu}$ & $\begin{array}{l}\text { a) } 0.15 \mathrm{M} \text { sodium oxalate } \\
\text { b) } 0.10 \mathrm{M} \text { sodium oxalate } \\
0.05 \mathrm{M} \text { ammonium oxalate } \\
\text { c) } 0.05 \mathrm{M} \text { sodium oxalate } \\
0.10 \mathrm{M} \text { ammonium oxalate }\end{array}$ & $\begin{array}{c}0 \\
9.1 \\
18.2\end{array}$ & $\begin{array}{r}25 \\
83 \\
120\end{array}$ \\
\hline $\operatorname{Tr}$ & $\begin{array}{l}\text { a) } 0.15 \mathrm{M} \text { sodium oxalate } \\
\text { b) } 0.15 \mathrm{M} \text { ammonium oxalate } \\
\text { c) } 0.07 \mathrm{M} \text { sodium citrate } \\
0.08 \mathrm{M} \text { sodium sulfate }\end{array}$ & $\begin{array}{c}0 \\
27.3 \\
0\end{array}$ & $\begin{array}{r}20 \\
125 \\
16\end{array}$ \\
\hline $\begin{array}{l}\mathrm{Br} \\
\bullet\end{array}$ & $\begin{array}{l}\text { a) } 0.07 \mathrm{M} \text { sodium citrate } \\
0.08 \mathrm{M} \text { sodium sulfate } \\
\text { b) } 0.07 \mathrm{M} \text { sodium citrate } \\
0.05 \mathrm{M} \text { sodium sulfate } \\
0.03 \mathrm{M} \text { ammonium sulfate } \\
\text { c) } 0.07 \mathrm{M} \text { sodium citrate } \\
0.08 \mathrm{M} \text { ammonium sulfate }\end{array}$ & $\begin{array}{c}0 \\
5.4 \\
14.4\end{array}$ & $\begin{array}{l}18 \\
72 \\
86\end{array}$ \\
\hline
\end{tabular}

Thirty ml. of blood were taken from each of 5 persons taking 0.1 gram atabrine daily. Ten $\mathrm{ml}$. of blood were added to $1 \mathrm{ml}$. of the various anticoagulant solutions. The plasmas were prepared in the usual manner. No blood was allowed to stand more than 10 minutes before centrifugation was begun.

0 , and if the point at which it intersects the abscissa is then taken as a plasma ammonium ion concentration of 0 , then the level of $23 \mu \mathrm{g}$. per liter (obtained with no added ammonium ion) corresponds to an ammonium ion concentration of 0.1 to 0.15 millimolar, which is in the range of ammonium ion concentration normally found in plasma (4).

In another experiment, blood from a person taking 0.1 gram atabrine daily was run into 5 per cent of its volume of $0.15 \mathrm{M}$ lithium oxalate. The blood was centrifuged immediately, the plasma drawn off and the cells resuspended in 0.9 per cent $\mathrm{NaCl}$ solution to make the original volume. The cell suspension was divided into 2 parts, to 1 of which was added enough ammonium chloride solu- 


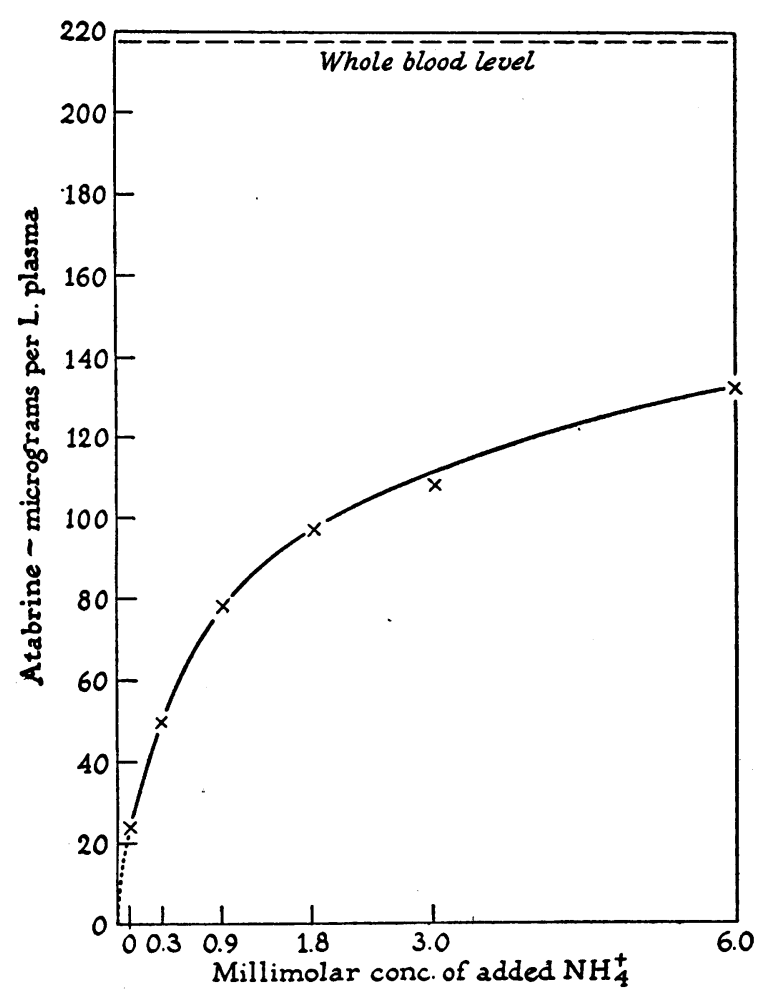

Fig. 1. The Relation Between the Concentration of Added Ammonium Ion and the Resulting Concentration of Atabrine in the Plasma

tion ( $0.1 \mathrm{ml}$. to $10 \mathrm{ml}$. suspension) to give an ammonium ion concentration of 0.1 millimolar. Both suspensions were centrifuged 10 minutes, and the supernatant fluids analyzed for atabrine, with the results shown in Table IV.

TABLE IV

Extraction of atabrine from blood cells resuspended in salt solution

Material

Supernatant from cell suspension in 0.9 per cent $\mathrm{NaCl}$ solution

Supernatant from cell suspension

in 0.9 per cent $\mathrm{NaCl}$ solution

plus 0.1 millimolar $\mathrm{NH}^{+}$,

Atabrine

Mg. per liter

7

14

Blood from person taking 0.1 gram atabrine daily.

In 1 experiment, the addition, to a portion of freshly drawn blood, of enough urea to give a 34 millimolar concentration of $\mathrm{NH}_{2}$, resulted in a plasma level of 31 , as compared with a level of 25 for the untreated blood. This was a much smaller increase than that obtained following the addition of considerably lower concentrations of ammonium salts.
(4) In order to note the effect of ammonium ion on the extraction of atabrine from tissues other than blood cells, comparable washed and weighed fragments of liver, removed from rats which had been fed atabrine for 2 weeks, were placed in 0.9 per cent $\mathrm{NaCl}$ solution and in 0.9 per cent ammonium chloride solution. The tissue was then removed, and the per cent of atabrine extracted from it was determined by measuring the concentration of atabrine in the fluid which had bathed it, and in the liver tissue. The results are given in Table V. Although the percentage of atabrine

TABLE V

Extraction of atabrine from liver tissue

\begin{tabular}{|c|c|c|c|}
\hline $\begin{array}{c}\text { Exp. } \\
\text { no. }\end{array}$ & Solution & Conditions of extraction & $\begin{array}{l}\text { Atabrine } \\
\text { extracted }\end{array}$ \\
\hline 1 & $\begin{array}{l}0.9 \text { per cent } \mathrm{NaCl} \\
0.9 \text { per cent } \mathrm{NH}_{4} \mathrm{Cl}\end{array}$ & $7 \mathrm{hrs}$. in refrigerator & $\begin{array}{c}\text { per cent } \\
0.4 \\
0.8\end{array}$ \\
\hline 2 & $\begin{array}{l}0.9 \text { per cent } \mathrm{NaCl} \\
0.9 \text { per cent } \mathrm{NH}_{4} \mathrm{Cl}\end{array}$ & $\begin{array}{l}1 \mathrm{hr} \text {. at room } \\
\text { temperature }\end{array}$ & $\begin{array}{l}0.5 \\
1.3\end{array}$ \\
\hline
\end{tabular}

extracted, even in the ammonium chloride solution, appears to be small, it must be realized that the figures are based on the total amount of atabrine in $10 \mathrm{ml}$. of fluid, as compared to the total amount originally present in a rather thick liver fragment, very rich in atabrine, and with only a relatively small surface actually exposed to the extracting fluid.

(5) In view of the effect of added ammonium ion in vitro on the relative distribution of atabrine between cells and plasma, it seemed probable that increasing the ammonium ion concentration of the blood in vivo should withdraw atabrine from the tissues into the plasma, and should increase the urinary excretion of atabrine. Such an increase in ammonium ion concentration might also produce a rise in the plasma level of atabrine.

Observations on a number of individuals have shown beyond doubt that there is a close relationship between the amounts of ammonia and atabrine excreted in the urine. An increase or decrease in the ammonia is accompanied by a corresponding increase or decrease in the atabrine. This is true for individual urine samples, as well as for 24-hour excretions. A typical result is 
TABLE VI

The effect of sodium bicarbonate and citrate on the urinary excretion of ammonia and atabrine

\begin{tabular}{c|c|l|c|c}
\hline \hline Subject & $\begin{array}{c}24 \text { hour } \\
\text { period }\end{array}$ & \multicolumn{2}{|c|}{ Treatment } & \multicolumn{2}{|c}{ Excreted } \\
\cline { 3 - 5 } F & 1st day & None & $\begin{array}{c}\text { Ammo- } \\
\text { nia }\end{array}$ & $\begin{array}{c}\text { Ata- } \\
\text { brine }\end{array}$ \\
\cline { 2 - 5 } 2nd day & $\begin{array}{c}\text { None } \\
706\end{array}$ & $\begin{array}{c}\text { mgm. } \\
4.0\end{array}$ \\
\hline 3rd day & $\begin{array}{l}10 \text { grams sodium bicar- } \\
\text { bonate plus 10 grams so- } \\
\text { dium citrate daily. }\end{array}$ & 119 & 0.7 \\
\hline 4 4th day & $\begin{array}{l}10 \text { grams sodium bicar- } \\
\text { bonate plus 10 grams so- } \\
\text { dium citrate daily. }\end{array}$ & 32 & 0.2 \\
\hline 8th day & $\begin{array}{l}\text { 5 grams ammonium } \\
\text { chloride daily beginning } \\
\text { on 7th day. }\end{array}$ & 475 & 2.2 \\
\hline
\end{tabular}

Twenty-four-hour urinary excretions. Subject F had discontinued atabrine 3 weeks before Period 1, and had been receiving ammonium chloride up to 2 days before Period 1. No atabrine during period of experiment.

shown in Table VI. This subject had been receiving ammonium chloride for about a week up until 2 days before the beginning of the observations. In the first 24-hour period, the ammonia excretion was still high (under the climatic conditions of New Guinea). It fell off during the second day, and the atabrine excretion likewise decreased. Both were then very sharply decreased by the administration of sodium bicarbonate and citrate, in spite of the fact that the volume of urine increased considerably. Several days later, following the administration of ammonium chloride, both the ammonia and atabrine excretions returned to the quantities obtaining on the second day.

Similar results are shown in Figures 2 and 3. The individual ( $\mathrm{T}$ ) who received ammonium chloride showed an increased ammonia and atabrine excretion. It is to be noted that the increase in atabrine excretion continued after the ammonia excretion had begun to decrease. The dosage of sodium acid phosphate taken by individual $R$ was insufficient to increase the ammonia excretion. The atabrine excretion similarly remained unchanged, but on the third day, when the ammonia excretion decreased, the atabrine excretion also decreased. Also shown in Figures 2 and 3 are 4 blood and plasma atabrine levels obtained during the 72-hour period of the observations. In

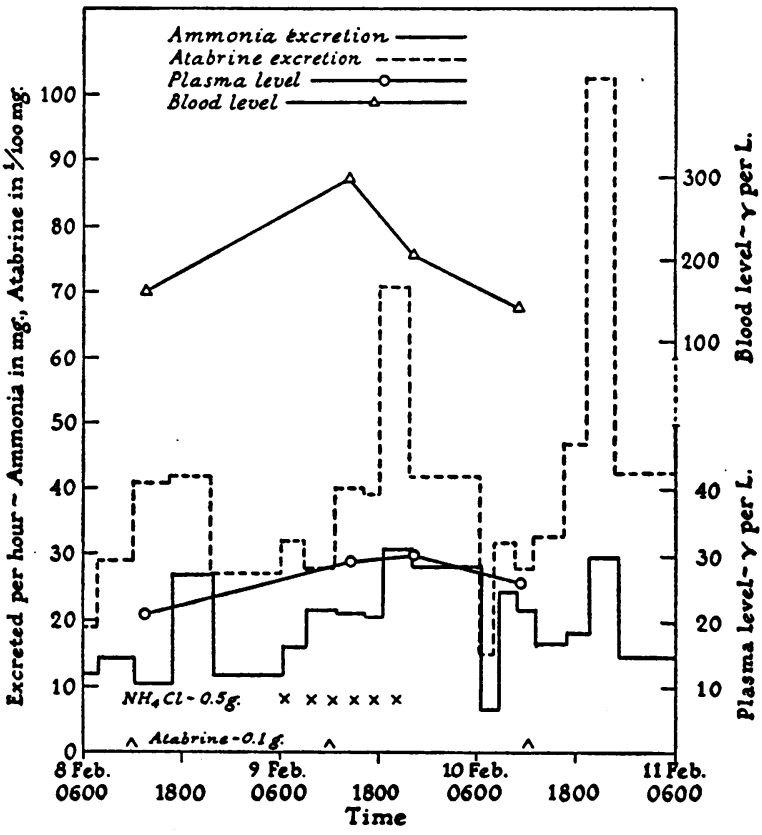

Fig. 2. Rates of Urinary Excretion of Ammonia and Atabrine, and Blood and Plasma Atabrine Levels, Over a 72-Hour Period, Including a Period of AmMONIUM ChLORIDE Administration

Subject T. 0.1 gram atabrine daily for 8 months.

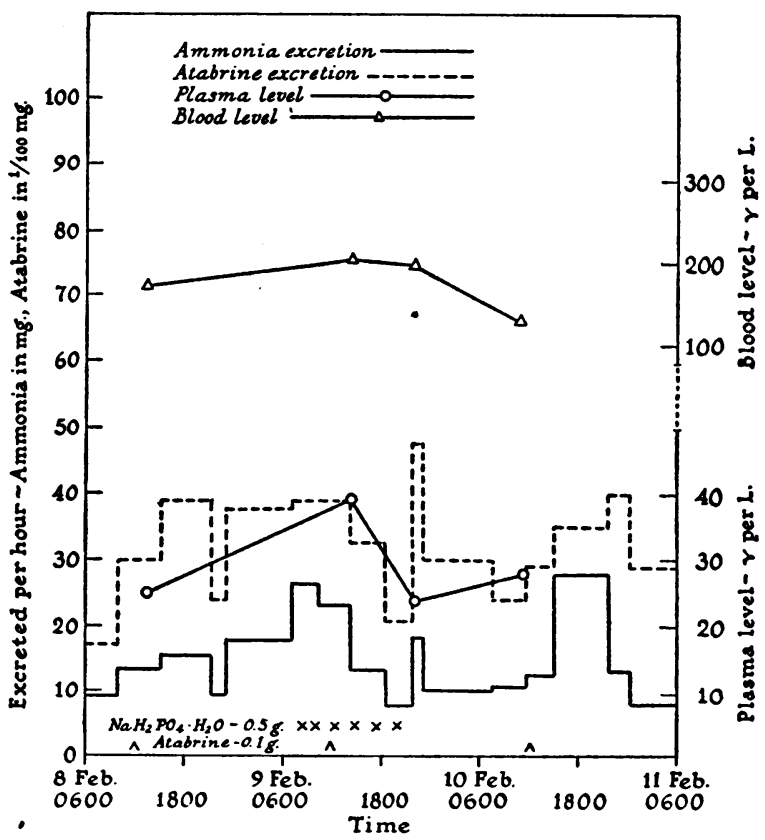

Fig. 3. Rates of Urinary Excretion of Ammonia and Atabrine, and Blood and Plasma Atabrine Levels, Over a 72-Hour Period, Including a Period of Acid Phosphate Administration

Subject R. 0.1 gram atabrine daily for 7 months. 


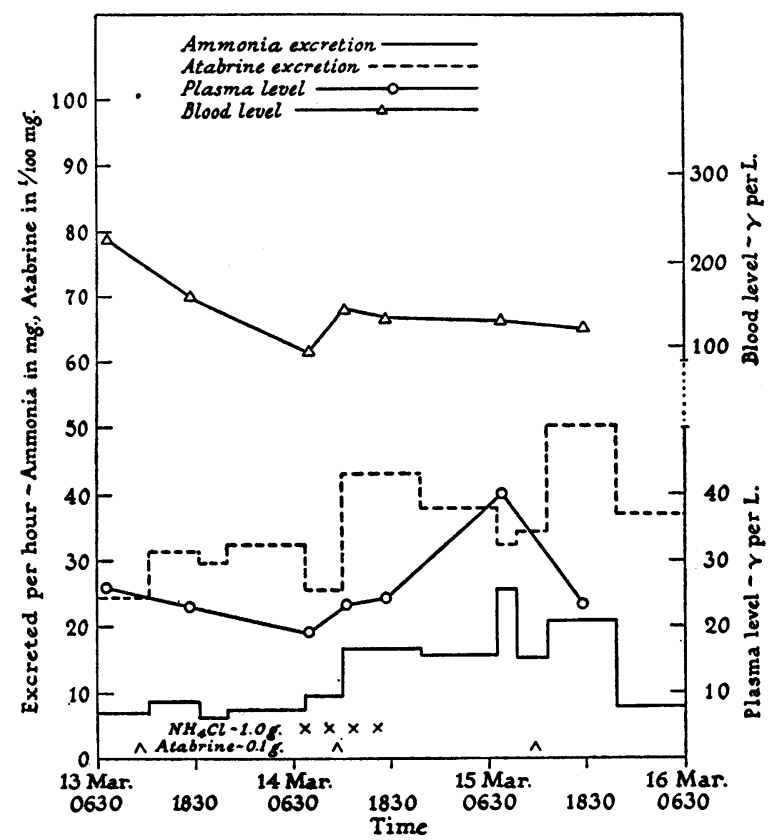

Fig. 4. Rates of Urinary Excretion of Ammonia and Atabrine, and Blood and Plasma Atabrine Levels, Over 72-Hour Period, Including a Period of Ammonium Chloride Administration

Subject T. 0.1 gram atabrine daily for 9 months.

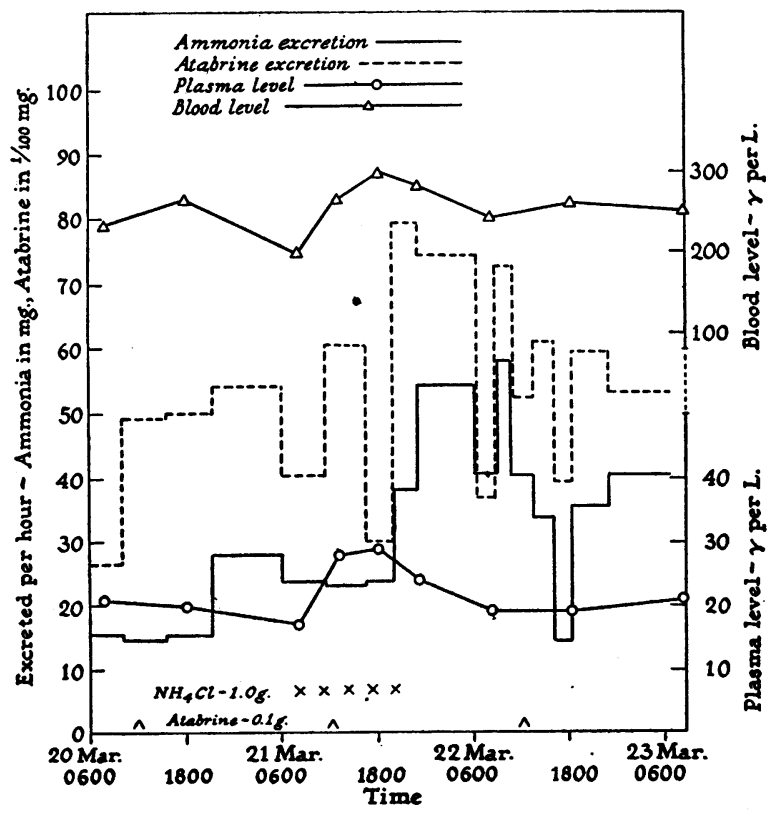

Fig. 5. Rates of Urinary Excretion of Ammonia and Atabrine, and Blood and Plasma Atabrine levels, Over a 72-Hour Period, Including a Period of AmMonium Chloride Administration

Subject S. 0.1 gram atabrine daily for 8 months. both individuals there was an increase in the plasma atabrine level during the administration of the salts.

The results of further observations of this type are shown in Figures 4 and 5. Subject $T$ again showed a lag between the period of ammonium chloride intake and the period of maximal excretion of ammonia and atabrine. This lag was less marked for subject S. Especially noteworthy are the changes in the plasma atabrine level. In both subjects the level began to rise soon after the beginning of ammonium chloride intake. In subject $\mathrm{T}$ the maximum observed level was not reached until early the following day. In subject $\mathrm{S}$ the maximum level occurred toward the end of the day of ammonium chloride administration. The changes in the whole blood level were less regular than the changes in the plasma level, but were in the same direction.

\section{DISCUSSION}

The effect of ammonium ion on plasma atabrine levels and on the urinary excretion of atabrine is of interest from several standpoints.

(1) The addition of ammonium ion must be scrupulously avoided when blood is being prepared for the determination of plasma atabrine levels.

(2) The amount of atabrine excreted in the urine is closely correlated with the amount of ammonia excreted. Rosenfeld, Jailer and Shannon (5) in 1944 observed that the feeding of ammonium chloride increased the renal excretion of atabrine, while the feeding of sodium bicarbonate decreased it. Emerson and Dole (6) at about the same time noted a correlation between urinary $\mathrm{pH}$ and the excretion of atabrine. The former authors attributed the effect to the assumed greater ease of diffusion of the free base, as compared with the acid salts of atabrine, across the cells of the distal segment of the nephron. It seems reasonable to suppose that the specific effect of ammonium ion on the equilibrium between intra- and extra-cellular atabrine also plays a part. A British Malaria Research Unit (7) found that, with a given plasma level, the urinary excretion of atabrine was more closely related to the urinary excretion of ammonia than to the $\mathrm{pH}$ or the titrable acidity of the urine. These workers set up equations 
which they used to calculate the plasma atabrine level from the determinations of the urinary ammonia and atabrine excretion. The data reported in the present paper, and a considerable volume of additional data which has since been collected in another connection, support the conclusion that urinary atabrine is determined largely by the body level of atabrine, and by the urinary excretion of ammonia. However, the data also show that the relation between urinary atabrine and urinary ammonia is not sufficiently constant in any one individual to permit an accurate estimate of the plasma atabrine level from measurements of the amounts of atabrine and ammonia excreted in the urine.

It would seem likely that increasing the urinary ammonia, as by the administration of ammonium chloride, should increase the rate of elimination of atabrine from individuals who have stopped taking the drug. This may, in certain instances, be of clinical value.

(3) Ever since the study of plasma atabrine levels was begun, it was observed that the plasma level varied among different individuals and in the same individual at different times, even though the dosage was kept uniform $(8,9)$. The latter variations became less after an individual had been on a particular dosage long enough to reach a balance between the tissue and plasma atabrine concentrations. In the past, it has not been possible by any experimental means (aside from a change in the dosage of atabrine) either to increase or to decrease the plasma atabrine level. The level seemed to vary quite independently of any known factor. The present results indicate that the ammonium ion concentration of plasma might be an important factor in determining the plasma atabrine level. This could be true in spite of the fact that the ingestion of ammonium salts does not materially influence the overall concentration of ammonia in the systemic blood (4). In the first place, as shown in Figure 1, rather small increases in ammonium ion concentration produce marked effects on the atabrine concentration of plasma in vitro. In the second place, the ingestion of ammonium salts does increase the ammonia concentration in the venous portal system. Moreover, the increased urinary excretion of ammonia, which follows the ingestion of ammonium salts, is probably accompanied by increased ammonia in the blood leaving the kidneys, since this blood normally contains about twice as much ammonia as blood entering the kidneys (10). Such local increases in ammonium ion concentration in organs such as the liver and kidney, which have a high concentration of atabrine when this drug is being taken, could conceivably be responsible for an increase in the plasma concentration of atabrine. A complete elucidation of the mechanism whereby the ingestion of ammonium chloride increases the plasma atabrine level of individuals taking atabrine would constitute an extensive physiological study which the authors were unable to undertake.

\section{SUMMARY}

1. It has been shown that low concentrations of ammonium ion rapidly extract atabrine in vitro from blood cells and from tissues.

2 . The urinary excretion of atabrine by individuals taking this drug was found to be closely correlated with the urinary excretion of ammonia. The amount of atabrine excreted in the urine could be increased or decreased by artificially increasing or decreasing the amount of ammonia excreted, as by the feeding of ammonium chloride, or of sodium bicarbonate and citrate.

3. A short period of administration of ammonium chloride to persons on a constant dosage of atabrine resulted in a temporary 50 per cent increase in plasma atabrine level during or just after the period of ammonium chloride intake.

\section{BIBLIOGRAPHY}

1. Brodie, B. B., and Udenfriend, S., The estimation of atabrine in biological fluids and tissues. J. Biol. Chem., 1943, 151, 299.

2. Peters, J. P., and Van Slyke, D. D., Quantitative Clinical Chemistry, Volume II : Methods, pp. 549, 577. The Williams and Wilkins Co., Baltimore, 1932.

3. Phillips, R. A., Van Slyke, D. D., Dole, V. P., Emerson, K., Jr., Hamilton, P. B., and Archibald, R. M., Copper sulfate method for measuring specific gravities of whole blood and plasma. Bull. U. S. Army M. Dept., no. 71, p. 66, 1943.

4. Peters, J. P., and Van Slyke, D. D., Quantitative Clinical Chemistry, Volume I: Interpretations, pp. 370-383. The Williams and Wilkins Co., Baltimore, 1931.

5. Rosenfeld, M., Jailer, J. W., and Shannon, J. A., Personal communication. 
6. Emerson, K., and Dole, V. P., Personal communication.

7. Army Malaria Research Unit, Oxford, Factors affecting the excretion of mepacrine in the urine. Ann. Trop. Med. and Parasitol., 1945, 39, 53.

8. Shannon, J. A., Report to Committee on Medical Research, July, 1943.

9. Shannon, J. A., Earle, D. P., Jr., Brodie, B. B., Tag- gart, J. V., and Berliner, R. W., The pharmacological basis for the rational use of atabrine in the treatment of malaria J. Pharmacol. and Exper. Therap., 1944, 81, 307.

10. Benedict, S. R., and Nash, T. P., Jr., The site of ammonia formation and the role of vomiting in ammonia elimination. J. Biol. Chem., 1926, 69, 381. 